\title{
MAKALAH \\ PEMBAGIAN DAN PERKEMBANGAN ANTROPOLOGI HUKUM
}

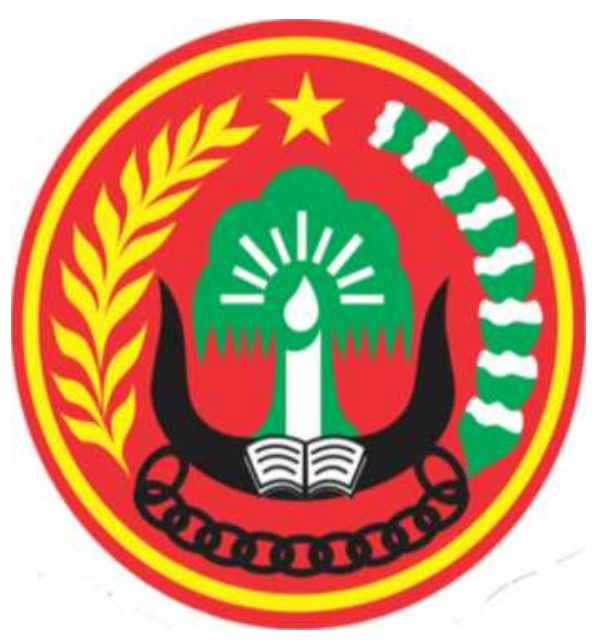

Disusun oleh:

$\begin{array}{ll}\text { Nama Mahasiswa } & \text { :Muhammad Yusuf } \\ \text { Email } & : m y u s u f 8 s u k m a @ g m a i l . c o m \\ \text { No BP } & : 2110003600169 \\ \text { Perguruan Tinggi } & : \text { Universitas Ekasakti } \\ & \text { Ilmu Hukum }\end{array}$




\section{BAB 1}

\section{PENDAHULUAN}

\section{A. LATAR BELAKANG}

Antropologi secara etimologis berasal dari bahasa Yunani. Kata anthroposberartimanusia dan logosberarti ilmu pengetahuan. Jadi antropologi adalah ilmu yang mempelajarimanusia. Dalam ilmu antropologi hukum dipelajari mengenai peran, status atau kedudukan,nilai, norma juga kebudayaan. Semua ini sangat erat kaitannya dengan ilmu antropologihukum. Sebelum berdirinya Komunisme, magistrat-magistrat Tiongkok, misalnya, tidakberurusan dengan menginterpretasi dan menerapkan aturan hukum untuk kasus-kasus konflikyang terjadi, namun menggunakan aturan hukum hanya sebagai pedoman teladan-teladanyang sangat berguna, tetapi tidak harus diteladani dalam kasus konkrit. Dalam antropologihukum tidak dapat membatasi diri pada isi peraturan-peraturan hukum dan bentuk- bentuksanksinya, tapi yang perlu diketahui dengan jelas adalah proses pembentukan hukumnya.Antropologi hukum adalah ilmu yang mempelajari tentang manusia dan budayanyakhusus dihidang hukum. Pengertian lain tentang hukum yaitu bahwa hukum diartikan sebagai prosespemerintahan. Proses pemerintahan itu mencangkup peraturan, pemerintahan dalam artisempit, penanggulangan serta peradilan. Hukum diartikan pula sebagai jalinan nilai. Nilai tersebut merupakan konsepsi abstrak di dalam diri manusia mengenai apa yang dianggap baikserta apa yang dianggap buruk. Hukum diartikan sebagai nilai yang merupakan salah satuunsur pandangan manusia mengenai hal-hal yang seharusnya dianuti karena dianggap baik,dan hal-hal yang seharusnya dihindari karena dianggap buruk. 


\section{BAB 2 PEMBAHASAN}

\section{Pengertian antapologi hukum}

Antropologi hukum adalah kajian antropologis terhadap makna sosial dari dan pentingnya hukum dengan menelaah bagaimana hukum dibuat termasuk bagaimana konteks sosial pembuatan hukum tersebut, bagaimana hukum mempertahankan dan mengubah institusi sosial lainnya, dan bagaimana hukum membangun perilaku sosial.] Namun seiring perkembangan zaman dan tatanan politik dunia pasca-Perang Dingin, cakupan kajian antropologi hukum meluas di antaranya membahas keterkaitan antara konflik sosial dengan kesenjangan ekonomi dan batasan-batasan hukum dalam melakukan rekayasa sosial. Antropologi hukum kini turut mengkaji hubungan antara politik dan hukum yang juga berubah dalam konteks pasca-Perang Dingin tersebut. Sebagai akibat dari perluasan cakupan tersebut, bahkan ada kalangan yang menyebut kajian antropologi hukum pada abad ke-19 sebagai kajian antropologi protolega

Pengertian lain tentang hukum yaitu bahwa hukum diartikan sebagai prosespemerintahan. Proses pemerintahan itu mencangkup peraturan, pemerintahan dalam arti sempit, penanggulangan serta peradilan. Hukum diartikan pula sebagai jalinan nilai. Nilai tersebut merupakan konsepsi abstrak di dalam diri manusia mengenai apa yang dianggap baikserta apa yang dianggap buruk. Hukum diartikan sebagai nilai yang merupakan salah satuunsur pandangan manusia mengenai hal-hal yang seharusnya dianuti karena dianggap baik,dan hal-hal yang seharusnya dihindari karena dianggap buruk

\section{Pembagian Antropologi hukum}

Antropologi mempelajari perkembangan kehidupan manusia dan budayanya, dengan cabang-cabang ilmu, diantaranya; ilmu PraSejarah untuk mempelajari kehidupan asal usul manusia, dan untuk mengetahui ragam bahasa manusia maka harus mempelajari Etnolinguistik, sedangkan ilmu yang mempelajari cara manusia berbangsa dan berbudaya disebut Etnologi.

Antropologi adalah studi ilmu yang mempelajari tentang manusia dari Aspek Budaya, Perilaku, Nilai, Keanekaragaman, dan lainnya.

Antropologi terbagi dalam: Antropologi Ekonomi, Antropologi Politik, Antropologi Pendidikan, dan Antropologi Hukum.

Antropologi Hukum merupakan ilmu yg mempelajari manusia dengan kebudayaan, khususnya di bidang Hukum, atau ilmu tentang Manusia dalam kaitannya dengan Kaidah-kaidah sosial yang bersifat Hukum.

\section{Sejarah dan Perkembangan Antropologi Hukum}

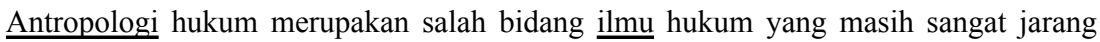
diketahui oleh masyarakat luas. Orang lebih mengenal antropologi sebagai bidang ilmu yang dekat dengan peristiwa sejarah dan budaya dan karena itu tidak mungkin memiliki kaitan dengan ilmu hukum. Namun inilah hukum, bidang ilmu yang sangat luas dan mencakup hampir seluruh aspek kehidupan manusia.

Awal 1970-an dapat dicatat sebagai formulasi dari perkembangan pendidikan $\underline{\mathrm{ilmu}}$ hukum empiris dengan menggunakan pendekatan sosiologis untuk mengkaji fenomenafenomena hukum dalam masyarakat sedang berkembang di Indonesia, yang dikenal kemudian sebagai disiplin sosiologihukum (sociology of law). Nama-nama akademisi hukum 
seperti Soeijono Soekanto (alm.) dari UI, Satjipto Rahardjo dari UNDIP, dan Sutandyo Wignyosubroto dari UNAIR dapat dicatat sebagai para perintis pengenalan mata kuliah sosiologi hukum di fakultas-fakultas hukum di Jawa.

Kemudian, sejak warsa 1980-an dunia pendidikan ilmu hukum di Indonesia semakin diperkaya dengan pengenalan studi-studi hukum empiris dengan menggunakan pendekatan antropologis. Untuk ini, T.O. Ihromi dan Valerine J.L. Kriekhoff dari UI bekeijasama dengan F. von Benda-Beckmann dari Wageningen Agriculture University the Netherlands dapat dinobatkan sebagai peletak dasar studi- studi antropologis tentang hukum yang kemudian dikenal sebagai antropologihukum (anthropology of law,legal anthropology, anthropological study of law). Makalah bersahaja ini mencoba untuk memberi pemahaman mengenai antropologi hukum sebagai bidang studi ilmu hukum empiris, dengan berfokus pada awal pemikiran studi-studi antropologis tentang hukum, pengembangan konsep hukum dalam studi antropologi hukum, perkembangan tematema kajian antropologi hukum, metodologi antropologi hukum, dan diskusi tema kemajemukan hukum dalam studi antropologi hukum.

Dari optik ilmu hukum, antropologi hukum pada dasarnya adalah sub disiplin ilmu hukum empiris yang memusatkan perhatiannya pada studi-studi hukum dengan menggunakan pendekatan antropologis. Kendati demikian, dari sudut pandang antropologi, sub disiplin antropologi budaya yang memfokuskan kajiannya pada fenomena empiris kehidupan hukum dalam masyarakatsecara luas dikenal sebagai antropologi hukum.[3] Antropologi hukum pada dasarnya mempelajari hubungan timbalbalik antara hukum dengan fenomena-fenomena sosial secara empiris dalam kehidupan masyarakat; bagaimana hukum berfungsi dalam kehidupan masyarakat, atau bagaimana hukum bekeija sebagai alat pengendalian sosial (social control) atau sarana untuk menjaga keteraturan sosial (social order) dalam masyarakat. Dengan kata lain, studi-studi antropologis mengenai hukum memberi perhatianpada segi-segi kebudayaan manusia yang berkaitan dengan fenomena hukum dalam fungsinya sebagai sarana menjaga keteraturan sosial atau alat pengendalian sosial (Pospisil, 1971 :x, 1973:538; Ihromi, 1989:8).

Karena itu, studi antropologis mengenai hukum secara khusus mempelajari prosesproses sosial di mana pengaturan mengenai hak dan kewajiban warga masyarakat diciptakan, dirobah, dimanipulasi, diinterpretasi, dan diimplementasikan oleh warga masyarakat (F. von Benda-Beckmann, 1979, 1986).

Awal pemikiran antropologis tentang hukum dimulai dengan studi-studi yang dilakukan oleh kalangan ahli antropologi dan bukan dari kalangan saijana hukum. Awal kelahiran antropologi hukum biasanya dikaitkan dengan karya klasik Sir Henry Maine yang bertajuk The Ancient Law yang diterbitkan pertama kali pada tahun 1861. Ia dipandang sebagai peletak dasar studi antropologis tentang hukum melalui introduksi teori evolusionistik (the evolusionistic theory) mengenai masyarakat dan hukum, yang secara ringkas menyatakan: hukum berkembang seiring dan sejalan dengan perkembangan masyarakat, dari masyarakat yang sederhana (primitive), tradisional, dan kesukuan (tribal) ke masyarakat yang kompleks dan modern, dan hukum yang inherent dengan masyarakat semula menekankan pada status kemudian wujudnya berkembang ke bentuk kontrak (Nader, 1965; Roberts, 1979; Krygier, 1980; Snyder, 1981).

Tema kajian pada fase awal studi-studi teoritis mengenai hukum dengan pendekatan antropologis lebih difokuskan pada fenomena hukum dalam masyarakat bersahaja (primitive), tradisional (traditional), dan kesukuan (tribal) dalam skala evolusi bentuk-bentuk organisasi sosial dan hukum yang mengiringi perkembangan masyarakat manusia. Sedangkan, metode kajian yang digunakan untuk memahami fenomena hukum dalam masyarakat adalah apa yang dikenal sebagai armchair methodology, yaitu metodologi untuk memahami hukum dalam 
perkembangan masyarakat melalui kajian-kajian yang dilakukan di belakang meja, sambil duduk di kursi empuk, dalam ruangan yang nyaman, dengan membaca dan menganalisis sebanyak mungkin documentary data yang bersumber dari catatan- catatan peijalanan para petualang atau pelancong, dari laporan-laporan berkala dan dokumen resmi para missionaris, pegawai sipil maupun para serdadu pemerintah kolonial dari daerah-daerah jajahannya (F. von BendaBeckmann, 1989).

Pada awal abad ke-20 metode kajian hukum dari belakang meja mulai ditinggalkan, dan mulai memasuki perkembangan metode studi lapangan (fieldwork methodology) dalam studi-studi antropologis tentang hukum. Karya Barton, misalnya, yang beijudul Ifugao Law yang dipublikasikan pertama kali pada tahun 1919 merupakan hasil dari field work yang intensif dalam masyarakat suku Ifugao di Pulau Luzon Philipina. Kemudian, muncul karya Malinowski beijudul Crime and Custom in Savage Society yang pertama kali dipublikasikan pada tahun 1926 adalah hasil studi lapangan yang komprehensif dalam masyarakat suku Trobrian di kawasan Lautan Pasific, dan seterusnya sampai sekarang metode field work menjadi metode khas dalam studi-studi antropologi hukum.

Tema-tema kajian yang dominan pada fase awal perkembangan antropologi hukum berkisar pada pertanyaan-pertanyaan : apakah hukum itu ? apakah ada hukum dalam masyarakat yang bersahaja, tradisional, dan

kesukuan ?; bagaimanakah hukum berujud dan beroperasi dalam kehidupan masyarakat ? Pada dekade tahun 1940-an sampai 1950-an tema-tema kajian antropologi hukum mulai bergeser ke mekanisme-mekanisme penyelesaian sengketa dalam masyarakat sederhana. Karya klasik dari Llewellyn dan Hoebel bertajuk The Cheyenne Way (1941) merupakan hasil studi lapangan kolaborasi dari seorang saijana hukum dengan ahli antropologi dalam masyarakat suku Cheyenne (suku Indian) di Amerika Serikat.

Kemudian, Hoebel mempublikasikan The Law of Primitive Man (1954), disusul dengan karya Gluckman mengenai hukum orang Barotse dan Lozi di Afrika, karya Bohannan mengenai hukum orang Tiv, karya Gulliver mengenai hukum orang Arusha dan Ndendeuli. Karya Fallers mengenai hukum dalam masyarakat suku Soga, dan karya Pospisil tentang hukum orang Kapauku di Papua. Fase perkembangan tema studi antropologi hukum ke arah mekanisme-mekanisme peneyelesaian sengketa seperti disebutkan di atas disebut oleh F. von Benda-Beckmann (1989) sebagai fase the anthropology of dispute settlements. Pada dekade tahun 1960-an tema studi-studi antropologi lebih memberi perhatian pada fenomena kemajemukan hukum atau pluralisme hukum. Tema pluralisme hukum pertama-tama difokuskan pada kemajemukan cara-cara penyelesaian melalui mekanisme tradisional, tetapi kemudian diarahkan kepada mekanisme dan institusi penyelesaian sengketa menurut hukum pemerintahkolonial dan pemerintah negara-negara yang sudah merdeka. Karya Bohannan, Gluckman, dan Gulliver misalnya, tidak secara sistematis memberi perhatian pada eksistensi mekanisme dan institusi penyelesaian sengketa menurut hukum kolonial dan hukum negara-negara sedang berkembang.

Sejak tahun 1970-an tema studi-studi antropologi hukum secara sistematis difokuskan pada hubungan antar institusi-institusi penyelesaian sengketa secara tradisional, neo-tradisional, dan menurut institusi hukum negara. Karya Nader dan Todd (1978) misalnya, memfokuskan kajiannya pada proses, mekanisme, dan institusi-institusi penyelesaian sengketa di komunitas masyarakattradisional dan modern 
di beberapa negara di dunia, melalui Berkeley Village Law Projects, menjadi karya yang memperlihatkan kecenderungan baru dari topik-topik studi antropologi hukum. Publikasi lain yang perlu dicatat adalah mekanisme penyelesaian sengketa di kalangan orang Togo di Afrika karya van Rouveroy van Nieuwaal, kemudian karya F. von BendaBeckmann (1979) dan K. von Benda-Beckmann (1984) yang memberi pemahaman tentang penyelesaian sengketa harta warisan di kalangan orang Minangkabau menurut pengadilan adat dan di pengadilan negeri di Sumatera Barat.

Fase selanjutnya studi pluralisme mekanisme penyelesaian sengketa mulai ditinggalkan, dan mulai diarahkan kepada studi-studi pluralisme hukum di luar penyelesaian sengketa. Karya Sally F. Moore (1978) misalnya, mengenai kemajemukan hukum agraris dalam kehidupan suku Kilimanjaro di Afrika, dan mekanisme dalam proses produksi pabrik garment terkenal di Amerika dapat dicatat sebagai perkembangan baru studi pluralisme hukum. Kemudian, studi-studi pluralisme hukum mulai difokuskan pada mekanisme jaminan sosial (social security), pasar dan perdagangan, mekanisme irigasi pertanian, institusi koperasi dan perkreditan di daerah pedesaan di negara-negara sedang berkembang. Studi-studi ini dikembangkan oleh AgrarianLawDepartmentWageningenAgricultureUniversity. Fase perkembangan tema pluralisme hukum yang menyoroti topik-topik penyelesaian sengketa maupun non penyelesaian sengketa, interaksi antara hukum negara, hukum

rakyat, atau dengan hukum agama disebut oleh F. von Benda-Beckmann (1989) sebagai fase the anthropology of legal pluralism. Kecenderungan yang berkembang sejak tahun 1970-an adalah penggunaan pendekatan sejarah dalam studi- studi antropologi hukum. Studi yang dilakukan Moore (1986), Snyder (1981), F. von Benda-Beckmann (1979), K. von Benda-Beckmann (1984) misalnya, secara eksplisit menggunakan kombinasi dimensi sejarah untuk menjelaskan interaksi institusi hukum negara (state law) dengan hukum rakyat (folk law) dalam kajian pluralisme hukum penyelesaian sengketa. 


\section{BAB 3 \\ PENUTUP}

\subsection{Kesimpulan}

Antropologi adalah salah satu cabang ilmu pengetahuan sosial yang mempelajari tentang budaya masyarakat suatu etnis tertentu. Antropologi lahir atau muncul berawal dari ketertarikan orang-orang Eropa yang melihat ciri-ciri fisik, adat istiadat, budaya yang berbeda dari apa yang dikenal di Eropa. Terbentuklah ilmu antropologi dengan melalui beberapa fase. Antropologi lebih memusatkan pada penduduk yang merupakan masyarakat tunggal, tunggal dalam arti kesatuan masyarakat yang tinggal daerah yang sama, antropologi mirip seperti sosiologi tetapi pada sosiologi lebih menitik beratkan pada masyarakat dan kehidupan sosialnya. Perkembangan antropologi terdiri atas 4 tahap yaitu; 1)

\section{Fase Pertama (Sebelum tahun 1800-an)}

Sekitar abad ke-15-16, bangsa-bangsa di Eropa mulai berlomba-lomba untuk menjelajahi dunia. Mulai dari Afrika, Amerika, Asia, hingga ke Australia. Dalam penjelajahannya mereka banyak menemukan hal-hal baru. Mereka juga banyak menjumpai suku-suku yang asing bagi mereka. Kisah-kisah petualangan dan penemuan mereka kemudian mereka catat di buku harian ataupun jumal peijalanan.

Fase Kedua (tahun 1800-an)

Pada fase ini, bahan-bahan etnografi tersebut telah disusun menjadi karangan- karangan berdasarkan cara berpikir evolusi masyarakat pada saat itu. masyarakat dan kebudayaan berevolusi secara perlahan-lahan dan dalam jangka waktu yang lama. Mereka menganggap bangsa-bangsa selain Eropa sebagai bangsa-bangsa primitif yang tertinggal, dan menganggap Eropa sebagai bangsa yang tinggi kebudayaannya Fase Ketiga (awal abad ke-20)

Pada fase ini, negara-negara di Eropa berlomba-lomba membangun koloni di benua lain seperti Asia, Amerika, Australia dan Afrika. Dalam rangka membangun koloni- koloni tersebut, muncul berbagai kendala seperti serangan dari bangsa asli, pemberontakan-pemberontakan, cuaca yang kurang cocok bagi bangsa Eropa serta hambatan-hambatan lain.

Fase Keempat (setelah tahun 1930-an)

Pada fase ini, Antropologi berkembang secara pesat. Kebudayaan-kebudayaan suku bangsa asli yang dijajah bangsa Eropa, mulai hilang akibat terpengaruh kebudayaan bangsa Eropa. 


\section{BAB 4}

\section{DAFTAR PUSTAKA}

Gokma Toni Parlindungan S, Asas Nebis In Idem Dalam Putusan Hakim Dalam Perkara Poligami Di Pengadilan Negeri Pasaman Sebagai Ceriminan Ius Consiiiuium, Volume 2, Nomor 1, 2020.

Gokma Toni Parlindungan S, Pengisian Jabaian Perangkai Nagari Pemekaran Di Pasaman Barai Dalam Rangka Pelaksanaan Oionomi Daerah, Ensiklopedia Of Journal, Vol 1 No 2 Edisi 2 Januari 2019,

Harniwati, Peralihan Hak Ulayat Menurut Undang-Undang Nomor 18 Tahim 2004, Volume 1, Nomor 3, 2019.

Jasmir, Pengembalian Status Hukum Tanah Ulayat Atas Hak Guna Usaha, Soumatera Law Review, Volume 1, Nomor 1, 2018.

Jumrawarsi Jumrawarsi, Neviyarni Suhaili, Peran Seorang Guru Dalam Menciptakan Lingkungan Belajar Yang Kondusif, Ensikopedia Education Review, Vol 2, No 3 (2020): Volume 2 No.3 Desember 2020

Mia Siratni, Proses Perkawinan Menurut Hukum Adatdi Kepulauan Mentawai Di Sebelum Dan Sesudah Berlakunya Undang-Undang Nomor 1 Tahim 1974 Tentang Perkawinan, Ensiklopedia Of Journal, Vol 1 No 2 Edisi 2 Januari 2019,

Remincel, Dimensi Hukum Pelanggaran Kecelakaan Lalu Dan Angkutan Jalan Lintas Di Indonesia, Ensiklopedia Social Review, Volume 1, Nomor 2, 2019.

R Amin, B Nurdin, Konflik Perwakafan Tanah Muhammadiyah di Nagari Singkarak Kabupaten Solok Indonesia 2015-2019, Soumatera Law Review, Volume 3, Nomor 1, 2020. 